\title{
PENERAPAN MODEL PEMBELAJARAN DISCOVERY LEARNING UNTUK MENINGKATKAN KEMAMPUAN PEMECAHAN MASALAH MATEMATIS SISWA PADA MATERI BANGUN RUANG SISI DATAR DI KELAS VIII MTsN 2 ACEH UTARA
}

\author{
Rosfarianti $^{1)}$, Rohantizani $^{2)}$, dan Muliana ${ }^{3)}$ \\ ${ }^{123}$ Program Studi Pendidikan Matematika, Universitas Malikussaleh, Aceh Utara \\ *Korespondensi Penulis. E-mail: rohantizani@unimal.ac.id
}

\begin{abstract}
Abstrak
Penelitian ini bertujuan untuk mengetahui peningkatan kemampuan pemecahan masalah matematis siswa yang diajarkan dengan model pembelajaran Discovery Learning lebih baik daripada kemampuan pemecahan masalah matematis siswa yang diajarkan dengan model pembelajaran konvensional. Penelitian menggunakan pendekatan kuantitatif dan jenis penelitian yang digunakan adalah quasy experiment dengan rancangan penelitian yaitu nonequivalent control group design. Populasi pada penelitian ini adalah seluruh siswa kelas VIII MTsN 2 Aceh Utara tahun pelajaran 2018/2019. Sampel penelitian ini adalah siswa kelas $\mathrm{VIII}_{\mathrm{A}}$ dan $\mathrm{VIII}_{\mathrm{F}}$ yang dipilih dengan teknik purposive sampling. Instrumen yang digunakan dalam penelitian ini adalah tes kemampuan pemecahan masalah matematis yaitu pretest dan posttest. Berdasarkan hasil penelitian dapat disimpulkan bahwa, peningkatan kemampuan pemecahan masalah matematis siswa yang diajarkan dengan model pembelajaran Discovery Learning lebih baik daripada kemampuan pemecahan masalah matematis siswa yang diajarkan dengan model pembelajaran konvensional pada materi bangun ruang sisi datar.
\end{abstract}

Kata Kunci: Discovery Learning, Pemecahan Masalah Matematis

\section{PENDAHULUAN}

Matematika merupakan ilmu yang sangat mendasari dalam kehidupan, karena matematika menyangkut dalam berbagai bidang baik bidang teknologi atau yang lebih sederhana dalam bidang jual beli. (As'ari, 2017) mengemukakan bahwa kecakapan atau kemahiran matematika merupakan bagian dari kecakapan hidup yang harus dimiliki siswa terutama dalam pengembangan penalaran, komunikasi, dan pemecahan masalah-masalah yang dihadapi dalam kehidupan sehari-hari.

((NCTM), 2000) merumuskan lima standar kemampuan matematika yang harus dimiliki siswa, yaitu kemampuan pemecahan masalah (problem solving), kemampuan penalaran dan pembuktian (reasoning and proof), kemampuan komunikasi (communication), kemampuan koneksi (connections), dan kemampuan representasi (representations).

Depdiknas (Mufidah, 2016)juga merumuskan bahwa pembelajaran matematika yang dilaksanakan di sekolah salah satunya bertujuan agar peserta didik memiliki kemampuan memecahkan masalah yang meliputi kemampuan memahami masalah, merancang model matematika, menyelesaikan model matematika, dan menafsirkan solusi yang diperoleh atau melakukan evaluasi.

Kemampuan pemecahan masalah matematis sangat erat kaitannya dengan keterampilan siswa dalam memecahkan setiap permasalahan yang diperoleh. Permasalahan tersebut baik di dalam dunia pendidikan maupun dalam kehidupan sehari-hari. Hal tersebut sejalan dengan (Hendriana, 2018) yang mengatakan "kemampuan pemecahan masalah 


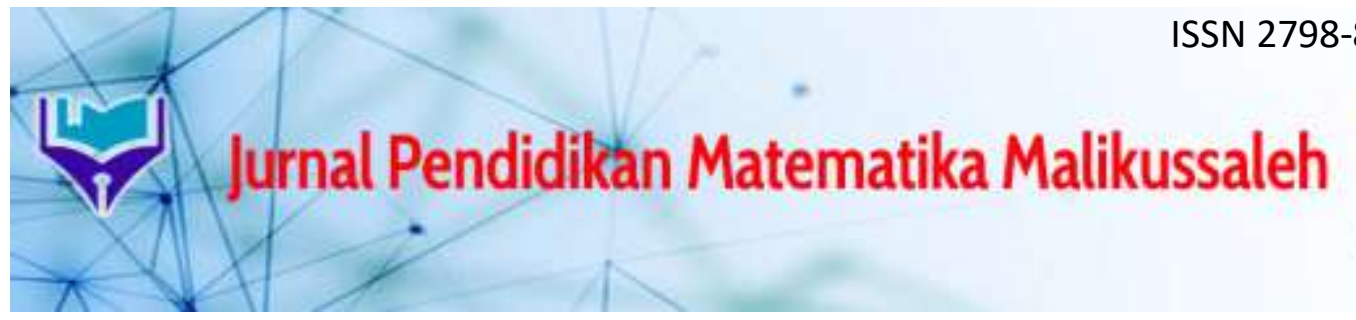

\section{Volume 1, Nomor 2, November 2021}

matematis merupakan satu kemampuan matematis yang penting dan perlu dikuasai oleh siswa yang belajar matematika". Menurut (Nurhasanah, 2018), "pemecahan masalah matematika adalah usaha untuk menyelesaikan permasalahan matematika dengan menggunakan pengetahuan yang telah didapat sebelumnya". Polya (Dwijayani, 2018)mendefenisikan pemecahan masalah sebagai usaha mencari jalan keluar dari suatu kesulitan, mencapai suatu tujuan yang tidak dengan segera dapat dicapai.

Menurut Polya (Mufidah, 2016) indikator kemampuan pemecahan masalah matematis yaitu sebagai berikut:

1. Memahami masalah (understanding the problem).

2. Merencanakan strategi dan prosedur pemecahan masalah (devising paln).

3. Melakukan prosedur pemecahan masalah (carrying out the plan).

4. Memeriksa kembali langkah-langkah yang dilakukan (looking back).

Dengan kata lain kemampuan pemecahan masalah matematis yaitu kemampuan siswa dalam menyelesaikan suatu persoalan atau masalah dengan melibatkan pemilihan prosedurprosedur matematika baik sudah diketahui sebelumnya maupun prosedur baru yang sesuai untuk memecahkan persoalan atau masalah tersebut. Indikator kemampuan pemecahan masalah matematis siswa yang digunakan dalam penelitian ini adalah sebagai berikut:

1. Memahami masalah, meliputi menyebutkan apa yang diketahui dan apa yang ditanyakan.

2. Merencanakan penyelesaian yaitu membuat model atau rumus matematika.

3. Melaksanakan penyelesaian yaitu menyelesaikan model matematika sesuai dengan langkah-langkah yang telah dibuat.

4. Memeriksa kembali meliputi, memeriksa langkah-langkah penyelesaian dan kebenaran hasil yang didapat.

Dari pernyataan di atas menunjukkan bahwa kemampuan pemecahan masalah matematis siswa sangatlah penting. (Yusri, 2018) mengatakan "pemecahan masalah merupakan kompetensi yang ditunjukkan kepada siswa didalam memahami serta memilih strategi pemecahan untuk menyelesaikan suatu permasalahan". Berdasarkan observasi dan wawancara dengan guru bidang studi matematika di MTsN 2 Aceh Utara mengatakan bahwa kemampuan pemecahan masalah matematis para siswa masih rendah terutama pada materi bangun ruang sisi datar. Hal tersebut membuat peneliti memberikan tes untuk melihat kemampuan pemecahan masalah matematis kepada lima orang siswa yang dipilih secara acak oleh guru. Dari keseluruhan siswa yang mengikuti tes, hanya $20 \%$ siswa bisa menyelesaikannya. Sementara $80 \%$ siswa lainnya tidak bisa. Dimulai dari proses menyelesaikan tes dan hasil tes menunjukkan kemampuan pemecahan masalah matematis siswa masih rendah, di mana siswa kurang lengkap dalam menuliskan yang diketahui dan ditanyakan serta siswa masih mengalami kesulitan dalam membuat atau merancang model matematika. Sehingga siswa tidak dapat memperoleh hasil tepat dan mengacu pada jawaban yang salah. 


\section{Jurnal Pendidikan Matematika Malikussaleh} r.1. 1 .

\section{Volume 1, Nomor 2, November 2021}

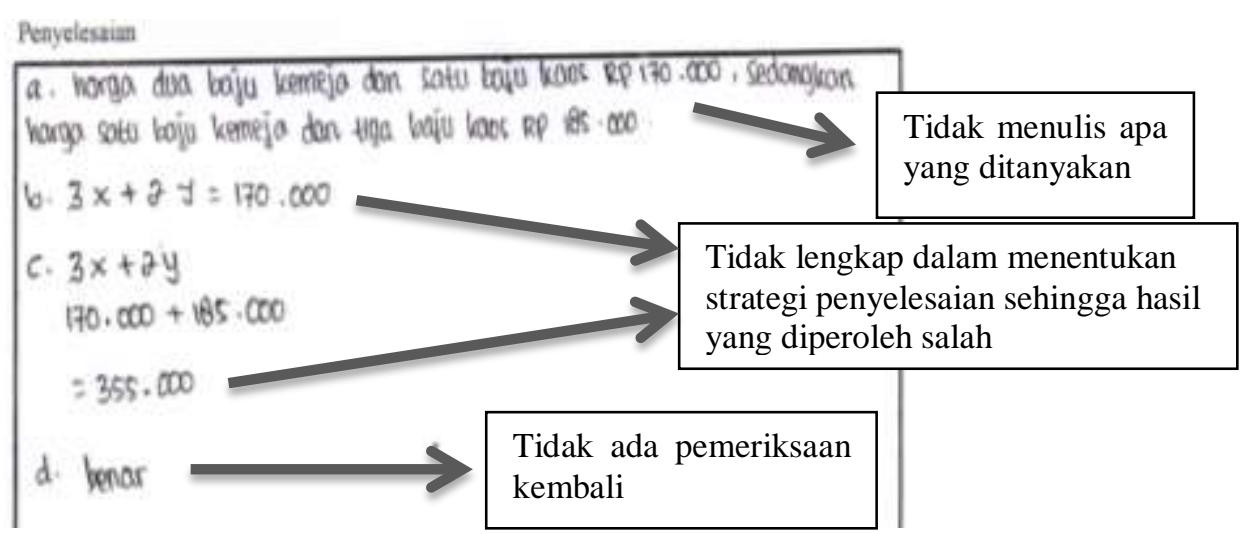

Gambar 1. Jawaban Siswa

Hal tersebut didukung dengan penelitian oleh (Nurhasanah, 2018) yang menyatakan kemampuan pemecahan masalah matematis siswa masih rendah dilihat dari hasil belajar yang kurang maksimal. Dari keseluruhan siswa kelas VIII hanya 26\% siswa yang memenuhi kriteria ketuntasan minimum (KKM) dan sisanya yaitu $74 \%$ siswa memiliki nilai di bawah KKM, sedangkan untuk KKM siswa kelas VIII SMP Islam Abata Malausma yaitu $\geq 64$. Siswa yang mendapatkan nilai kurang dari KKM masih banyak.

Penggunaan model Discovery Learning dalam proses pembelajaran matematika merupakan solusi untuk meningkat kemampuan pemecahan masalah matematis siswa. Model ini lebih menekankan pada penemuan yang sebelumnya belum diketahui oleh siswa, menggunakan permasalahan yang berhubungan dengan kehidupan sehari-hari, sehingga siswa harus mampu menyelesaikan permasalahan tersebut dengan langkah-langkah yang sesuai. Model Discovery Learning merupakan model pembelajaran yang dirancang untuk menemukan suatu konsep atau prinsip.

Hal tersebut sejalan dengan pendapat (As'ari, 2017), untuk menunjang proses belajar diperlukan lingkungan yang memfasilitasi rasa ingin tahu siswa pada tahap eksplorasi. Lingkungan ini dinamakan Discovery Learning Environment, yaitu lingkungan di mana siswa dapat melakukan eksplorasi, penemuan-penemuan baru yang belum dikenal atau pengertian yang mirip dengan yang sudah diketahui. Lingkungan seperti ini bertujuan agar siswa dalam proses belajar dapat berjalan dengan baik dan lebih kreatif. (Afandi, 2013), mengatakan "dengan menggunakan metode Discovery Learning pembelajaran akan lebih bermakna mengena kepada siswa. Sebab siswa disini tidak hanya sebagai pendengar setia, namun dalam metode pembelajaran ini siswa dituntut aktif dalam pembelajaran".

Menurut Syah (Mariyaningsih \& Hidayati, M, 2018)langkah-langkah atau sintaks pembelajaran Discovery adalah sebagai berikut:

1. Stimulation (memberi stimulus/rangsangan)

2. Problem Statement (mengidentifikasi masalah)

3. Data Collecting (mengumpulkan data)

4. Data Processing (pengolahan data)

5. Verification (pembuktian)

6. Generalization (menyimpulkan)

Menurut Djamarah (Afandi, 2013) Discovery Learning adalah belajar mencari dan menemukan sendiri. Dalam proses belajar mengajar ini guru menyajikan bahan pelajaran yang tidak berbentuk final, tetapi anak didik diberi peluang untuk mencari dan menemukan 


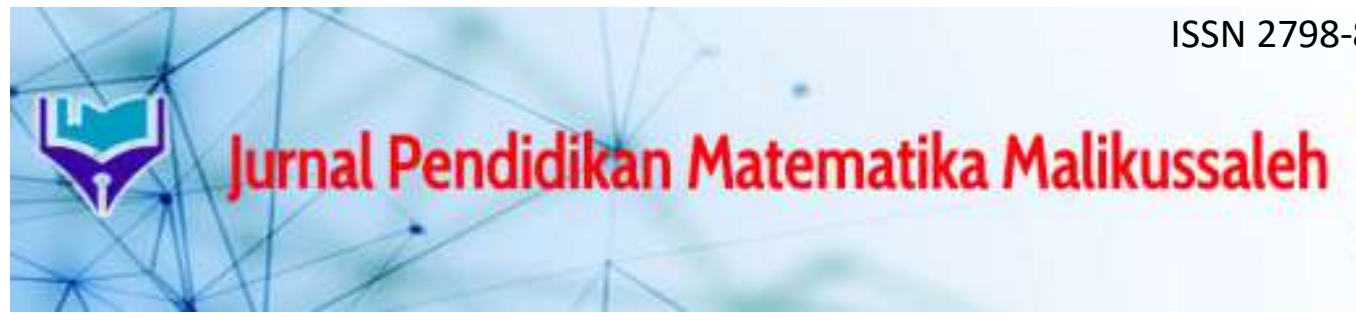

\section{Volume 1, Nomor 2, November 2021}

sendiri dengan menggunakan teknik pendekatan pemecahan masalah. Menurut Salmon (Imayati, 2018) model Discovery Learning merupakan cara belajar aktif dengan menemukan sendiri, menyelidiki sendiri, maka hasil yang diperoleh oleh siswa akan tahan lama dalam ingatan, serta posisi guru di kelas sebagai pembimbing dan mengarahkan kegiatan pembelajaran sesuai dengan tujuan pembelajaran.

Berdasarkan beberapa pendapat di atas maka dapat peneliti simpulkan Discovery Learning adalah proses belajar yang mendorong siswa untuk menemukan konsep dengan mengumpulkan informasi dan mengolahnya sehingga menjadi suatu konsep yang utuh. Sehingga memberikan kesempatan kepada siswa untuk berkreatifitas dalam menemukan pengalaman belajar yang menyenangkan.

Berdasarkan uraian di atas, maka yang menjadi hipotesis dalam penelitian ini yang akan diuji kebenarannya adalah: Peningkatan kemampuan pemecahan masalah matematis siswa yang diajarkan dengan model pembelajaran Discovery Learning lebih baik daripada kemampuan pemecahan masalah matematis siswa yang diajarkan dengan model pembelajaran konvensional pada materi bangun ruang sisi datar di kelas VIII MTsN 2 Aceh Utara.

\section{METODE PENELITIAN Jenis Penelitian}

Penelitian ini menggunakan pendekatan kuantitatif, Jenis penelitian yang digunakan dalam penelitian ini adalah quasi experimen (eksperimen semu). Menurut (Sugiyono, 2017), "quasi experimen ini mempunyai kelompok kontrol, tetapi tidak dapat berfungsi sepenuhnya untuk mengontrol variabel-variabel luar yang mempengaruhi pelaksanaan eksperimen".

\section{Waktu dan Tempat Penelitian}

Penelitian ini dilakukan di MTsN 2 Aceh Utara pada siswa kelas VIII yang beralamat di Jalan Banda Aceh - Medan Aceh Utara. Penelitian ini dilaksanakan pada semester genap tahun ajaran 2018/2019.

\section{Populasi dan Sampel Penelitian}

Populasi dalam penelitian ini adalah seluruh siswa kelas VIII yang terdiri atas delapan kelas dengan rata-rata 22 siswa perkelas. Adapun yang menjadi sampel dalam penelitian ini adalah siswa sebanyak dua kelas dari delapan kelas yang dipilih secara sampling purposive. "Sampling purposive adalah teknik penentuan sampel dengan pertimbangan tertentu" (Sugiyono, 2017). Maka yang menjadi kelas eksperimen menggunakan pembelajaran dengan model Discovery Learning yaitu $\mathrm{VIII}_{\mathrm{A}}$ dan kelas kontrol yang menggunakan pembelajaran dengan model konvesional yaitu $\mathrm{VIII}_{\mathrm{F}}$.

\section{Prosedur Penelitian}

Rancangan penelitian yang digunakan pada penelitian ini yaitu Nonequivalent Control Group Design. (Sugiyono, 2017) mengemukakan "Nonequivalent Control Group Design adalah pengambilan atau penentuan sampel untuk kelas eksperimen dan kelas kontrol tidak diambil secara acak". Rancangan penelitiannya adalah sebagai berikut: 


\section{Jurnal Pendidikan Matematika Malikussaleh}

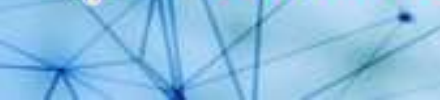

\section{Volume 1, Nomor 2, November 2021}

Tabel 1 Rancangan Penelitian

\begin{tabular}{|l|c|c|c|}
\hline \multicolumn{1}{|c|}{ Kelompok Perlakuan } & Pretest & Perlakuan & Posttest \\
\hline Model Pembelajaran Discovery Learning & $\mathrm{O}_{1}$ & $\mathrm{X}_{1}$ & $\mathrm{O}_{2}$ \\
\hline Pembelajaran konvensional & $\mathrm{O}_{1}$ & - & $\mathrm{O}_{2}$ \\
\hline
\end{tabular}

Sumber: dimodifikasi dari (Sugiyono, 2017)

Keterangan : $\mathrm{O}_{1}=$ Pretest untuk kelas Discovery Learning dan kelas konvensional $\mathrm{X}_{1}=$ Perlakuan Model pembelajaran Discovery Learning

$\mathrm{O}_{2}=$ Posttest untuk kelas Discovery Learning dan kelas konvensional

\section{Data, Instrumen, Teknik Pengumpulan Data}

Data dari penelitian ini yaitu data tes kemampuan pemecahan masalah matematis siswa, berupa hasil pretest dan posttest. Instrumen yang digunakan yaitu tes. Tes digunakan untuk mengukur penguasaan dan kemampuan pemecahan masalah matematis siswa dengan model pembelajaran Discovery Learning dan model konvensional. Soal tes terdiri dari 4 soal berbentuk uraian yang menyangkut materi bangun ruang sisi datar.

\section{Teknik Analisis Data}

Data yang telah diperoleh dari pembelajaran yang menggunakan model Discovery Learning dan pembelajaran dengan model konvensional yaitu data tes kemampuan pemecahan masalah matematis siswa, berupa hasil pretest dan posttest dari kedua kelas tersebut. Untuk pengolahan data penulis menggunakan bantuan SPSS versi 17. Kemudian untuk melihat peningkatan kemampuan pemecahan masalah matematis siswa dihitung menggunakan $N-$ Gain.

Peningkatan kemampuan pemecahan masalah matematis siswa dihitung menggunakan $N-$ Gain. Menurut Hake (Mufidah, 2016) besarnya peningkatan dihitung dengan rumus gain ternormalisasi $($ normalized gain $)=\mathrm{g}$, yaitu:

$$
N-\text { Gain }=\frac{\text { posttest score }- \text { pretest score }}{\text { maximum possible score }- \text { pretest score }}
$$

Berdasarkan Meltzer (Gusvina, 2018) menafsirkan kriteria $N$-Gain dapat dilihat pada tabel berikut ini.

Tabel 2 Kriteria Nilai Gain Score Hake

\begin{tabular}{|c|c|}
\hline Skor Gain & Kategori \\
\hline $\mathrm{g} \geq 0.7$ & Tinggi \\
\hline $0.3 \leq \mathrm{g}<0.7$ & Sedang \\
\hline $\mathrm{g}<0.3$ & Rendah \\
\hline
\end{tabular}

Selanjutnya data hasil skor $N$-Gain kemampuan pemecahan masalah matematis siswa diuji normalitas dan homogenitas, guna untuk melihat normal dan homogen tidaknya data tersebut, sebelum dilakukannya uji-t dengan taraf signifikan $\alpha=0.05$. 
Volume 1, Nomor 2, November 2021

\section{HASIL DAN PEMBAHASAN}

Pengolahan data terhadap 39 siswa yang terdiri dari 19 siswa kelas eksperimen dan 20 siswa kelas kontrol menggunakan SPSS versi 17 diperoleh hasil tes kemampuan pemecahan masalah matematis siswa ecara ringkas disajikan dalam bentuk tabel yaitu sebagai berikut.

Tabel 3 Statistik Deskriptif Skor Pretest, Posttest, dan N-Gain Kemampuan Pemecahan Masalah Matematis

\begin{tabular}{|c|c|c|c|c|c|c|c|}
\hline \multicolumn{2}{|c|}{ Hasil } & $N$ & $X_{\min }$ & $X_{\text {maks }}$ & $\bar{x}$ & $\%$ & $S$ \\
\hline \multirow{2}{*}{ Eksperimen } & Pretest & 19 & 12 & 26 & 18,68 & 29,1 & 3,93 \\
\hline & Posttest & 19 & 44 & 64 & 55,42 & 86,5 & 7,14 \\
\hline \multirow{2}{*}{ Kontrol } & Pretest & 20 & 4 & 24 & 13,55 & 21,1 & 5,67 \\
\hline & Posttest & 20 & 26 & 55 & 36,35 & 56,7 & 7,68 \\
\hline \multicolumn{2}{|c|}{$N$-Gain } & 39 & 0,18 & 1 & 0,63 & 38,4 & 0,23 \\
\hline
\end{tabular}

Berdasakan tabel di atas menunjukkan bahwa rataan skor pretest kelas ekperimen dan kelas kontrol secara berturut-turut yaitu 18.68 dan 13.55 dari skor maksimal ideal 64 . Sementara rataan skor posttest kelas eksperimen dan kelas kontrol secara berturut-turut yaitu 55.42 dan 36.35. Hal tersebut menunjukkan bahwa terdapat peningkatan kemampuan pemecahan masalah matematis siswa setelah memperoleh pembelajaran.

Secara umum peningkatan kemampuan siswa dilihat dari peningkatan skor pretest ke skor posttest dan klasifikasinya menggunakan data gain ternormalisasi. Berikut rekapitulasi rataan skor $\mathrm{N}$-Gain kemampuan pemecahan masalah matematis siswa baik kelas eksperimen maupun kontrol disajikan dalam tabel 4.

Tabel 4 Rataan dan Klasifikasi Skor $N$-Gain Kemampuan Pemecahan

\begin{tabular}{|l|c|c|}
\multicolumn{3}{c}{ Masalah Matematis Siswa } \\
\hline Kelas & Rataan N-Gain & Klasifikasi \\
\hline Eksperimen & 0.82 & Tinggi \\
\hline Kontrol & 0.45 & Sedang \\
\hline
\end{tabular}

Dari tabel di atas dapat dibuat diagram perbandingan antara rataan skor $\mathrm{N}$-Gain kelas eksperimen dan kelas kontrol yaitu sebagai berikut.

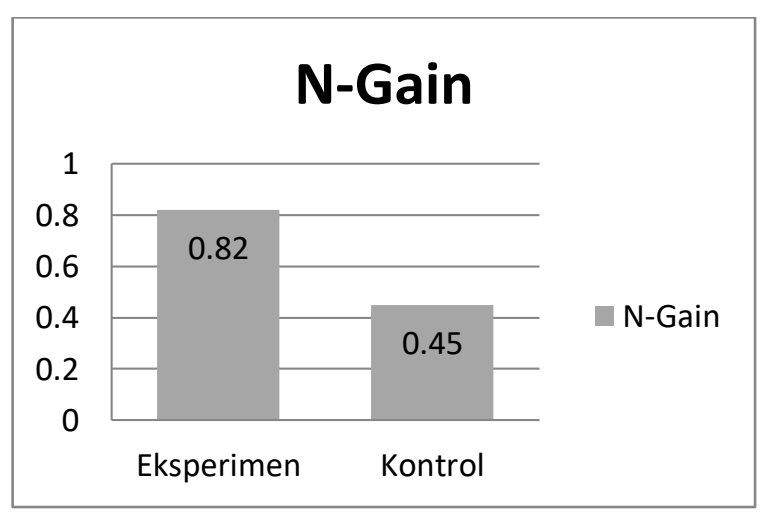

Gambar 2. Diagram Perbandingan Rataan Skor N-Gain Kemampuan Pemecahan Masalah Matematis Siswa 


\section{Volume 1, Nomor 2, November 2021}

Dari diagram di atas, terlihat bahwa siswa kelas eksperimen yang diajarkan menggunakan model Discovery Learning memiliki skor $N$-Gain yang lebih tinggi dari pada siswa kelas kontrol yang diajarkan menggunakan model pembelajaran konvensional. Hal tersebut menunjukkan bahwa peningkatan kemampuan pemecahan masalah matematis siswa kelas eksperimen lebih tinggi dari pada kemampuan pemecahan masalah matematis siswa kelas kontrol.

Selanjutnya, untuk mengetahui apakah peningkatan kemampuan pemecahan masalah matematis siswa yang diajarkan menggunakan model pembelajaran Discovery Learning lebih baik dari pada kemampuan pemecahan masalah matematis siswa yang diajarkan menggunakan model konvensional. Akan dilakukan uji hipotesis, tetapi sebelumnya dilakukan uji prasyarat yaitu uji normalitas dan homogenitas. Jika uji prasyarat tesebut memenuhi kriteia maka dilanjutkan dengan uji hipotesis. Berikut rangkuman hasil pengujian normalitas data $N$-Gain menggunakan SPSS versi 17 disajikan pada tabel di bawah ini.

Tabel 5 Uji Normalitas Skor N-Gain Kemampuan Pemecahan Masalah Matematis Siswa

Tests of Normality

\begin{tabular}{|ll|c|c|c|c|c|c|}
\hline & \multicolumn{3}{|c|}{ Kolmogorov-Smirnov $^{\mathrm{a}}$} & \multicolumn{3}{c|}{ Shapiro-Wilk } \\
\cline { 2 - 8 } & Kelompok & Statistic & $\mathrm{df}$ & Sig. & Statistic & Df & Sig. \\
\hline Ngain & Eksperimen & .137 & 19 & $.200^{*}$ & .910 & 19 & .074 \\
& Kontrol & .088 & 20 & $.200^{*}$ & .988 & 20 & .994 \\
\hline
\end{tabular}

a. Lilliefors Significance Correction

*. This is a lower bound of the true significance.

Dari tabel 5 diperoleh nilai signifikan kelas eksperimen 0.074 dan nilai signifikan kelas kontrol 0.994. Sehingga nilai dari kedua kelas tersebut lebih dari $\alpha=0.05 \quad(>\alpha=$ 0.05) maka $\mathrm{H}_{0}$ diterima. Jadi dapat disimpulkan yang bahwa data skor $N$-Gain kemampuan pemecahan masalah matematis siswa berdistribusi normal. Kemudian dilanjutkan dengan uji homogenitas varians terhadap skor $N$-Gain kemampuan pemecahan masalah matematis siswa Berikut hasil uji homogenitas data yang disajikan pada tabel 6 di bawah ini.

Tabel 6 Uji Homogenitas Skor $N$-Gain Kemampuan

Pemecahan Masalah Matematis Siswa

Test of Homogeneity of Variances

Ngain

\begin{tabular}{|c|c|c|c|}
\hline Levene Statistic & df1 & df2 & Sig. \\
\hline .276 & 1 & 37 & .602 \\
\hline
\end{tabular}

Berdasarkan tabel 6, menunjukkan hasil uji homogen data skor $N$-Gain kemampuan pemecahan masalah matematis siswa diperoleh nilai signifikan 0.602 yang berarti terima $\mathrm{H}_{0}$ karena sig $>$ taraf signifikan $(\alpha=0.05)$. Jadi dapat disimpulkan yang bahwa data skor $N$-Gain kemampuan pemecahan masalah matematis siswa berasal dari varians yang homogen. Setelah melakukan uji normalitas dan uji homogenitas varians pada skor $\mathrm{N}$-Gain diperoleh bahwa data tersebut berdistribusi normal dan homogen. Maka selanjutnya dilanjutkan ke uji t menggunakan Compare Means Independent-Samples t-Test (SPSS versi 17).

Adapun hipotesis yang diajukan pada penelitian ini yaitu sebagai berikut: 


\section{Jurnal Pendidikan Matematika Malikussaleh}

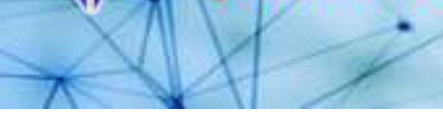

\section{Volume 1, Nomor 2, November 2021}

$H_{0}: \mu_{1}=\mu_{2}$ : Peningkatan kemampuan pemecahan masalah matematis siswa yang diajarkan dengan model pembelajaran Discovery Learning sama dengan kemampuan pemecahan masalah matematis siswa yang diajarkan dengan model pembelajaran konvensional pada materi bangun ruang sisi datar di kelas VIII MTsN 2 Aceh Utara.

$H a: \mu_{1}>\mu_{2}$ : Peningkatan kemampuan pemecahan masalah matematis siswa yang diajarkan dengan model pembelajaran Discovery Learning lebih baik daripada kemampuan pemecahan masalah matematis siswa yang diajarkan dengan model pembelajaran konvensional pada materi bangun ruang sisi datar di kelas VIII MTsN 2 Aceh Utara.

Keterangan:

$\mu_{1}$ : Rataan skor $N$-Gain kemampuan pemecahan masalah matematis siswa kelas eksperimen.

$\mu_{2}$ : Rataan skor $N$-Gain kemampuan pemecahan masalah matematis siswa kelas kontrol.

Berikut rangkuman hasil uji hipotesis yang disajikan dalam bentuk tabel.

Tabel 7 Uji t Skor N-Gain Kemampuan Pemecahan Masalah Matematis Siswa Independent Samples Test

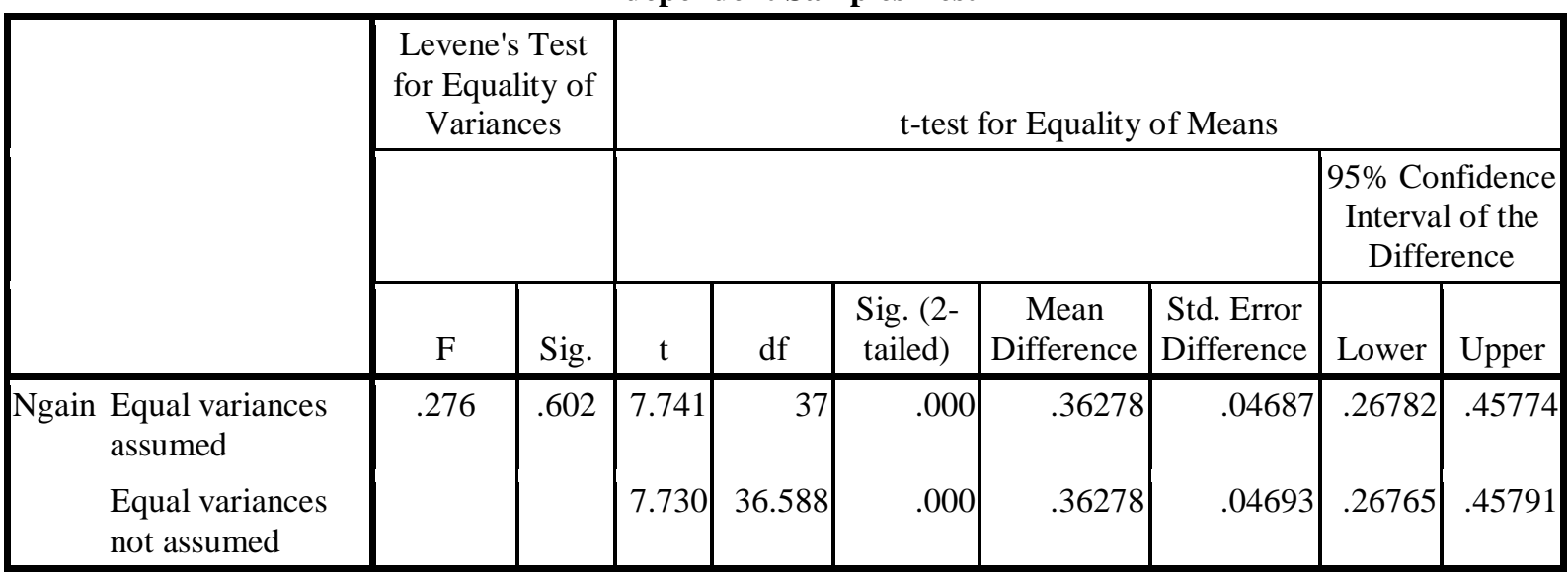

Berdasarkan tabel 7 diperoleh hasil uji t yaitu 0.000 yang berarti $0.000<0.05$ maka, tolak $H_{0}$. Jadi dapat disimpulkan bahwa peningkatan kemampuan pemecahan masalah matematis siswa yang diajarkan menggunakan model Discovery Learning lebih baik daripada kemampuan pemecahan masalah matematis siswa yang diajarkan menggunakan model pembelajaran konvensional.

Berdasarkan hasil penelitian, dapat disimpulkan bahwa peningkatan kemampuan pemecahan masalah matematis siswa yang diajarkan dengan model pembelajaran Discovery Learning lebih baik daripada kemampuan pemecahan masalah matematis siswa yang diajarkan dengan model pembelajaran konvensional.

Ada beberapa faktor yang mempengaruhi peningkatan kemampuan pemecahan masalah matematis siswa pada kelas eksperimen lebih baik daripada kemampuan pemecahan masalah matematis siswa kelas kontrol, diantaranya yaitu fase-fase ataupun langkah-langkah 


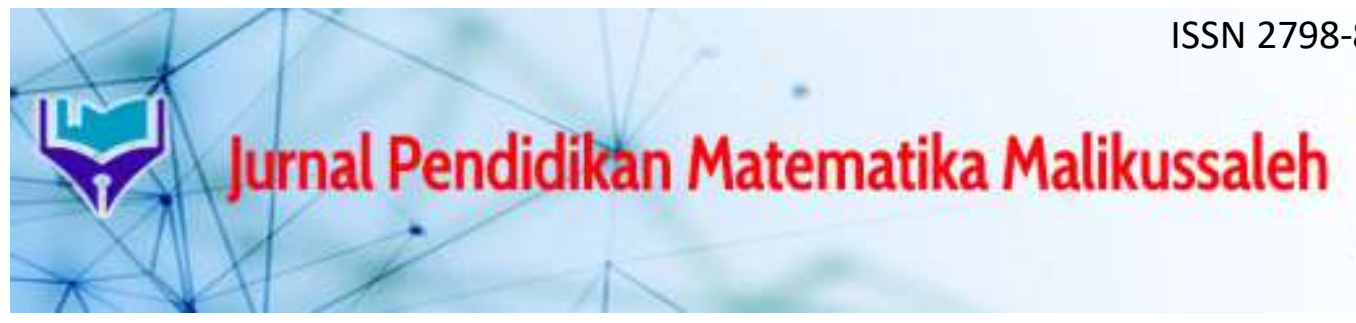

\section{Volume 1, Nomor 2, November 2021}

pada model pembelajaran Discovery Learning. Berikut akan dijelaskan mengenai langkahlangkah pembelajarannya.

1. Memahami masalah

Pada model pembelajaran Discovery learning, indikator memahami masalah didukung dengan fase Stimulation dan Problem Statement. Diawali dengan guru mengajukan pertanyaan terbuka seperti bagaimanakah cara menghitung luas ruangan kelas ini? Sehingga menimbulkan pertanyaan kepada siswa dan keinginan untuk menyelidiki sendiri. Problem statement, yaitu tahap yang memberikan kesempatan kepada siswa untuk mengidentifikasi masalah yang terdapat di LAS.

2. Merencanakan penyelesaian

Pada model pembelajaran Discovery Learning, indikator merencanakan penyelesaian didukung dengan fase data collections. Data collection ialah tahap yang mengarahkan siswa untuk mengumpulkan data atau informasi yang relevan dengan masalah yang telah diidentifikasi sebelumnya.

3. Melaksanakan penyelesaian

Pada model pembelajaran Discovery Learning, indikator melaksanakan penyelesaian didukung dengan fase data processing. Pada tahap ini ini siswa terlibat aktif dalam mengolah data dan informasi yang telah diperoleh sebelumnya. Setiap anggota kelompok berani dalam mengeluarkan pendapat mengenai prosedur penyelesainnya.

4. Memeriksa kembali

Pada model pembelajaran Discovery Learning, indikator memeriksa kembali didukung dengan fase verification dan generalization. Verification, tahap ini merupakan tahap yang melatih siswa untuk berani dalam menyampaikan hasil kerja kelompoknya di depan kelas. Dibagian ini siswa dilatih untuk bertanggung jawab salah satunya yaitu siswa harus benar-benar menguasai materi atau memahami hasil diskusi dikarenakan semua siswa mempunyai kesempatan yang sama dalam mempresentasikan hasil diskusinya di depan kelas. Generalization merupakan tahap atau fase penarikan kesimpulan dari semua hasil diskusi yang telah dilakukan.

Berdasarkan langkah-langkah yang telah dipaparkan di atas, maka terlihat bahwa dengan penerapan model Discovery Learning dapat meningkatkan kemampuan pemecahan masalah matematis siswa.

\section{KESIMPULAN}

Berdasarkan hasil penelitian dan pembahasan mengenai penerapan model pembelajaran Discovery Learning untuk meningkatkan kemampuan pemecahan masalah matematis siswa pada materi bangun ruang sisi datar di kelas VIII MTsN 2 Aceh Utara, maka dapat disimpulkan bahwa peningkatan kemampuan pemecahan masalah matematis siswa yang diajarkan dengan model pembelajaran Discovery Learning lebih baik daripada kemampuan pemecahan masalah matematis siswa yang diajarkan dengan model pembelajaran konvensional pada materi bangun ruang sisi datar di kelas VIII MTsN 2 Aceh Utara. 


\section{Jurnal Pendidikan Matematika Malikussaleh}

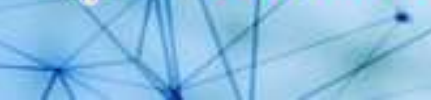

Volume 1, Nomor 2, November 2021

\section{DAFTAR PUSTAKA}

Afandi, M. d. (2013). Model dan Metode Pembelajaran di Sekolah. Semarang: Unissula Press.

As'ari, A. R. (2017). Buku Guru Matematika SMP/MTs Kelas VIII. Jakarta: Kementrian Pendidikan dan Kebudayaan.

Dwijayani, N. M. (2018). Pembelajaran Lingkaran Berbantuan Permasalahan Matematika Realistik untuk Meningkatkan Kemampuan Pemecahan Masalah Siswa. Jurnal Pendidikan Matematika, Volume 1, No. 7: 34-47.

Gusvina, F. (2018). Pengaruh Model Discovery Learning Terhadap Peningkatan Hasil Belajar Matematika Siswa SMP/MTs. Skripsi, UIN Ar-Raniry.

Hendriana, H. d. (2018). Hard Skill dan Soft Skills Matematik Siswa. Bandung: PT. Rafika Aditama.

Imayati. (2018). Peranan Model Pembelajaran Discovery Learning Untuk Meningkatkan Pemahaman Matematis dan Disposisi Matematis. Jurnal Matematics Paedagogic, Volume 1, No. 3: 9-18.

Mariyaningsih, N., \& Hidayati, M. (2018). Bukan Kelas Biasa. Surakarta: CV Kenyata Group.

Mufidah, D. (2016). Pengaruh Pembelajaran Kooperatif Tipe Core Terhadap Kemampuan Pemecahan Masalah Matematis Siswa. Skripsi: Bandar Lampung: Universitas Lampung.

(NCTM), N. C. (2000). Executive Summary Principles and Standards for School Mathematics. Reston, USA: NCTM.

Nurhasanah, D. E. (2018). Penggunaan Model Pembelajaran Discovery Learning untuk Meningkatkan Kemampuan Pemecahan Masalah pada Siswa SMP. Jurnal Didactical Mathematics, Volume 1, No. 1:21-32.

Sugiyono. (2017). Metode Penelitian Pendidikan Pendekatan Kuantitatif, Kualitatif, $R$ dan D. Bandung: Alfabet.

Yusri, A. Y. (2018). Pengaruh Model Pembelajaran Problem Based Learning Terhadap Kemampuan Pemecahan Masalah Matematika Siswa Kelas VII di SMP Negeri Pangkajene. Jurnal Mosharafa, Volume 1, No. 7: 51-62. 